\title{
Socio-Economic Status: A Determinant of Abuse among Rural Adolescents
}

\author{
Sukhminder Kaur $_{1}$, Suman Verma 2
}

\begin{abstract}
ABATRACT
Child abuse is a social problem which varies from family to family in different cultures and societies. It has indelible effects on physical and psychological wellbeing of a child. The present study was carried out in India on a sample of 310 abused adolescents identified from a larger sample of 1000 from six rural locations using a Personal Information Sheet, a Self-structured Assessment Performa relating to abuse and a Socio-economic Status Scale. Analysis of Variance and t-Test were used to analyze the data. Inferences of the study revealed high prevalence of abuse in the low socio-economic status families. Girls experienced more of emotional abuse irrespective of their socio-economic status. No significant differences in the abuse experienced by younger and older adolescents were recorded in low and middle class families; however the younger adolescents experienced more abuse in high socio-economic status families.
\end{abstract}

Keywords : Abuse, adolescents, rural, socio- economic status

\section{INTRODUCTION}

Child abuse, a perennial problem is recognized differently in different societies. In a country like India, it is a minutely recognized social phenomenon regardless of social strata (Deb, 2006). The roots of child abuse and neglect lie in the structure of family. Though family is a child's first and longest lasting context for development and parents are universally important in the lives of children. But it is still a source of abuse towards children for reasons that parents still believe in physical punishment to discipline the children and they punish them under the mask of behaviour modification. It is a fact that since ancient times, children were and are still in many cultures regarded as property of their parents and are treated according to their parents wish since child rearing and discipline are considered family matters (Walker, Bonner \& Kaufman, 1988).

${ }^{1}$ Senior Extension Specialist, Department of Human Development, Punjab Agricultural University, Ludhiana, Punjab, India

${ }^{2}$ Department of Child Development, Government Home Science College, Chandigarh, Punjab, India 
Since there is no universal standard for optimal child rearing, hence there is also no universal standard what constitutes child abuse. In the Indian context, child abuse was examined by a committee formed at the National Seminar on Child Abuse in India, held under the aegis of National Institute of Public Cooperation and Child Development, New Delhi (NIPCCD, 1988). The concerned committee evolved the definition as "Child Abuse and Neglect is the intentional, non-accidental injury, maltreatment of children by parents, caretakers, employers or others including those individuals representing governmental/non-governmental bodies, which may lead to temporary or permanent impairment of their physical, mental and psychosocial development, disability or death". However, comparing commonalities among definitions of child abuse from 58 countries (cited in Krug, Dalberg, Mercy, Zwi, \& Lozano, 2002) the WHO Consultation on Child Abuse Prevention in the year 1999 drafted the definition as "Child abuse or maltreatment constitutes all forms of physical and/or emotional ill-treatment, sexual abuse, neglect or negligent treatment or commercial or other exploitation, resulting in actual or potential harm to the child's health, survival, development or dignity in the context of a relationship of responsibility, trust or power".

Etiology of abuse has been viewed in terms of the interplay between individual, family and social factors in relation to both past (e.g. exposure to abuse as child) and present (e.g. a demanding child) events. The parents' learning history, interpersonal experiences and intrinsic capabilities are regarded as predisposing characteristics presumed to be important contributors to an abusive pattern (Parke and Collmer, 1975). The potential role of the child in provoking abuse is also acknowledged. The conditions under which the child is reared and the methods used by the parents, particularly their punitive methods, may help to explain why some adults are predisposed to abusive behaviour given certain settings (Kewalramani, 1992). The causes of child abuse in Indian families seem to be poverty, lack of educational and health facilities especially in rural areas, wrong perception about the value of education, wrong cultural practices like child marriages, characteristics of the child and the parents, social situation and socialization process (Sharan, 1995; Deb, 2006). Of course, other social settings also influence children's development and behaviour but in power and breadth of influence, none equals the family.

Risk of physical punishment has been reported to be greatest among parents from lower socioeconomic status family background and whose own parents were controlling, restrictive and overprotective (Horwood et al 2007) whereas middle income parents show more warmth and indulgence (Singh \& Khokhar 2005). National Research Council (1993) revealed that children whose fathers are unemployed or work part time are more likely to be abused compared to children of fathers with full time jobs. Those in the lowest income groups have 2 or 3 times greater rates of abuse than upper income group of families. Because people with poor economic background tend to have large families. Consequently, children in these families are deprived of basic minimal facilities that is adequate nutrition, education, health services and care and loving environment. They are brought up in hostile and unhealthy environment and are usually a target for parental stress due to economic constraints. 
Studies reveal illiteracy, unemployment, conjugal discord, lack of attachment and history of victimization in the early life of parents are the aggravating factors for parents' cruelty towards children and socio-pathic family environment (Deb and Senapati, 1993). Economic stress and inadequate educational resources undermine the functioning of parents, particularly mothers and out of such stress emerges child abuse. However, Steinmetz (1978) points out that child abuse can be found in families across the spectrum of socio-economic status. Keeping in mind the above facts and varied view points, the present study was planned with the objectives (1) to determine the differences in the extent of abuse among adolescents from low, middle and high socio-economic status rural families and (2) to find out the age and gender differences in abuse among adolescents with respect to their socio-economic status. It was considered worthwhile to conduct this study in the rural area of the state where no prior work in this area exists. Moreover, more than sixty eight percent $(68.84 \%)$ people in our country live in villages (Census of India, 2011) and any research study which does not include village as its unit, is not a true representation of the existing situation. Though adolescents form a substantial part of Punjab population but there is practically no information recorded as regards their abuse and hence this study.

\section{METHOD}

Study Location: Rural locations of Punjab state in India.

Study Design : Cross-sectional exploratory study.

Sample size : A sample of 310 adolescents was selected based on the extent of abuse experienced by them.

Inclusion criteria : (a) Abused adolescents aged 10-16 years (b) They should be from different socio-economic strata (low, middle and high)

(c) From rural locations of Punjab state

Assessment Tool: A Personal information Sheet, A self- structured Assessment Performa relating to abuse and a Socio-economic status scale.

\section{PROCEDURE}

The study aimed at documentation of abuse among adolescents in different socio-economic strata (low, middle and high) in rural locations of Punjab state in India. One block out of 12 blocks of the Ludhiana district in the Punjab state was selected by using simple random sampling 
technique which forms the central part of the district and ten percent of the villages were randomly selected. Following selection of the villages, village leaders viz Sarpanch, President Mahila Mandal, Incharge Anganwari Centre and Principals of the village schools were contacted to establish rapport with the villagers since it was not possible to collect information on such a sensitive issue without having prior contacts with the villagers and taking them into confidence. A survey of the villages was conducted in two phases using a multistage sampling procedure. In the first phase, a larger sample of 1000 adolescents aged 10 to16 years was drawn and in the second phase, a sample of 310 adolescents was selected for the study based on the extent of abuse experienced by the adolescents which was assessed using a self- structured Assessment Performa relating to physical and emotional abuse among the adolescents. Further, a Socioeconomic status scale developed by Kulshrestha (1988) especially for rural areas was used to identify abused adolescents in different socio-economic status rural families. The scale consists of five component variables viz parents' and siblings' occupation and education, economic indicators, cultural and psychological indicators. The reliability and validity of the scale is 0.85 and 0.81 , respectively.

Data were collected through personally interviewing the adolescents and focus group discussions and analyzed by using Analysis of Variance and t-Test.

\section{Operational definition}

It was imperative to define child/adolescent abuse in the context of the present study relating to rural area of the state since the meaning of abuse varies in different cultures and societies which was done by conducting a pilot study in the selected villages to assess awareness, perception and understanding of parents and adolescents with respect to abuse, by using a self structured Interview schedule, reviewing relevant literature, and by holding focus group discussions with the adolescents. Thirty families (5 from each selected village) representing different socioeconomic strata and having adolescents falling in the age groups of 10-16 years of both the genders (boys and girls), were randomly selected and their opinions and that of their parents and grandparents regarding the use and relevance/irrelevance of various disciplinary techniques were sought. Based on their opinions the abuse was defined as follows.

Acts committed by parents/caretakers with respect to the child which leave physical marks/scars on his/her body as well as the acts which do not leave any physical scars but are equally or more harmful to the child and keep him/her perturbed. Behaviours such as depriving the child of privileges (withdrawal of love, restrictions to play with friends etc.), scolding, verbal abuse, use of physical violence (leading to injuries such as bruises, wounds, bleeding, burns and fracture), attitude of parents towards problems of adolescents, lack of parental interest in child's activities; criticizing, rejecting, authoritarian, reluctant, blaming, discouraging and belittling attitude of parents, were included under the domain of abuse 


\section{RESULTS}

The differences in the extent of abuse experienced by the rural adolescents from different socioeconomic status (SES) families are presented below.

Results of One-way ANOVA in Table 1 highlight the highly significant differences in the extent of cumulative $(\mathrm{F}=15.67 ; \mathrm{p}<.001)$ and physical $(\mathrm{F}=14.28 ; \mathrm{p}<.001)$ abuse and marginally significant differences in the emotional abuse $(\mathrm{F}=3.84 ; \mathrm{p}<.05)$ in different socio-economic strata. It is obvious from the data contained in the Table that abuse is more pronounced in the low socio-economic status families as compared to that in the middle and high socio-economic status families since the mean scores for physical, emotional as well as cumulative abuse are high.

Table 1

Mean scores and ANOVA showing extent of abuse among adolescents from different socioeconomic status (SES) families $(N=310)$

\begin{tabular}{|c|c|c|c|c|}
\hline \multirow{2}{*}{ Abuse } & \multicolumn{3}{|c|}{ Mean score } & \multirow{2}{*}{$\begin{array}{l}\text { Composite } \\
\text { mean }\end{array}$} \\
\hline & $\begin{array}{l}\text { Low SES } \\
(\mathrm{N}=103)\end{array}$ & $\begin{array}{l}\text { Middle SES } \\
(\mathrm{N}=150)\end{array}$ & $\begin{array}{l}\text { High SES } \\
(\mathrm{N}=57)\end{array}$ & \\
\hline Physical (P) & 101.06 & 88.14 & 89.33 & 92.84 \\
\hline Emotional (E) & 48.17 & 46.55 & 45.05 & 46.59 \\
\hline $\begin{array}{l}\text { Cumulative } \\
(\mathrm{P}+\mathrm{E})\end{array}$ & 149.23 & 134.69 & 134.38 & 139.43 \\
\hline Composite mean & 99.49 & 89.79 & 89.59 & \\
\hline \multicolumn{5}{|l|}{ ANOVA } \\
\hline Source & $\mathrm{df}$ & M S & F Ratio & \\
\hline $\begin{array}{l}\text { Physical abuse } \\
\text { SES } \\
\text { Error }\end{array}$ & $\begin{array}{l}2 \\
307\end{array}$ & $\begin{array}{l}258.21 \\
18.08\end{array}$ & $14.28 * * *$ & \\
\hline $\begin{array}{l}\text { Emotional abuse } \\
\text { SES } \\
\text { Error }\end{array}$ & $\begin{array}{l}2 \\
307\end{array}$ & $\begin{array}{l}186.14 \\
48.47\end{array}$ & $3.84 *$ & \\
\hline $\begin{array}{l}\text { Cumulative }(\mathrm{P}+\mathrm{E}) \\
\text { SES } \\
\text { Error }\end{array}$ & $\begin{array}{l}2 \\
307\end{array}$ & $\begin{array}{l}374.98 \\
23.93\end{array}$ & $15.67 * * *$ & \\
\hline
\end{tabular}

$$
* \mathrm{p}<.05, * * * \mathrm{p}<.001
$$


Gender-wise comparison of abuse among adolescents from different socio-economic status families is shown in Table 2. There are no significant differences in physical abuse among adolescents from different socio-economic strata. However, with respect to emotional abuse, there are marginally significant differences; the scores of female adolescents being

\section{Table 2}

Abuse among adolescents from different socio-economic status (SES) families with respect to their gender $(N=310)$

\begin{tabular}{|c|c|c|c|c|c|c|c|c|c|}
\hline \multirow{3}{*}{ Abuse } & \multicolumn{9}{|c|}{$\begin{array}{l}\text { Mean (SD) level of abuse among male and female adolescents from different } \\
\text { SES families }\end{array}$} \\
\hline & \multicolumn{3}{|c|}{ Low $(\mathrm{N}=103)$} & \multicolumn{3}{|c|}{ Middle $(\mathrm{N}=150)$} & \multicolumn{3}{|c|}{ High $(\mathrm{N}=57)$} \\
\hline & Male & Female & $\begin{array}{ll}\mathrm{t} & - \\
\text { value }\end{array}$ & Male & Female & $\begin{array}{l}\mathrm{t}- \\
\text { value }\end{array}$ & Male & Female & $\begin{array}{ll}\mathrm{t}- \\
\text { value }\end{array}$ \\
\hline $\begin{array}{l}\text { Physical } \\
\text { (P) }\end{array}$ & $\begin{array}{l}102.46 \\
(16.70)\end{array}$ & $\begin{array}{l}99.63 \\
(16.83)\end{array}$ & 0.86 & $\begin{array}{l}88.89 \\
(14.69)\end{array}$ & $\begin{array}{l}87.24 \\
(16.69)\end{array}$ & 0.64 & $\begin{array}{l}91.55 \\
(12.92)\end{array}$ & $\begin{array}{l}86.29 \\
(12.98)\end{array}$ & 1.51 \\
\hline $\begin{array}{l}\text { Emotional } \\
\text { (E) }\end{array}$ & $\begin{array}{l}46.21 \\
(6.48)\end{array}$ & $\begin{array}{l}50.16 \\
(8.97)\end{array}$ & $2.57 *$ & $\begin{array}{l}45.48 \\
(6.88)\end{array}$ & $\begin{array}{l}47.84 \\
(7.36)\end{array}$ & $2.03^{*}$ & $\begin{array}{l}43.73 \\
(6.35)\end{array}$ & $\begin{array}{l}46.88 \\
(4.61)\end{array}$ & $2.06 *$ \\
\hline $\begin{array}{l}\text { Cumulative } \\
(\mathrm{P}+\mathrm{E})\end{array}$ & $\begin{array}{l}148.67 \\
(20.71)\end{array}$ & $\begin{array}{l}149.78 \\
(21.63)\end{array}$ & 0.27 & $\begin{array}{l}134.37 \\
(16.45)\end{array}$ & $\begin{array}{l}135.0 \\
(15.77)\end{array}$ & 0.26 & $\begin{array}{l}135.27 \\
(14.92)\end{array}$ & $\begin{array}{l}133.17 \\
(14.52)\end{array}$ & 0.53 \\
\hline
\end{tabular}

$* \mathrm{p}<.05$

High on emotional abuse $(\mathrm{t}$-values $=2.57$ and $2.03 ; \mathrm{p}<.05)$ with respect to low and middle socio-economic status and scores of male adolescents being more $(\mathrm{t}$-value $=2.06 ; \mathrm{p}<.05)$ in high socio-economic status families.

A perusal of the data in Table 3 relating to age-wise comparison of abuse among adolescents from different socio-economic status families reveals significant differences among adolescents; 
the younger adolescents $(10-14$ years $)$ from middle ( $\mathrm{t}$-value $=2.03 ; \mathrm{p}<.05)$ and high socioeconomic status families ( $\mathrm{t}$-value $=2.47 ; \mathrm{p}<.05$ ) experience more of physical abuse whereas the emotional abuse is more pronounced among older adolescents from the middle socio-economic status families $(\mathrm{t}$-value $=3.18 ; \mathrm{p}<.01)$.

Table 3

Abuse among adolescents from different socio-economic status (SES) families with respect to their age $(N=310)$

\begin{tabular}{|c|c|c|c|c|c|c|c|c|c|}
\hline \multirow{3}{*}{ Abuse } & \multicolumn{9}{|c|}{$\begin{array}{l}\text { Mean (SD) level of abuse among adolescents of different ages from different SES } \\
\text { families }\end{array}$} \\
\hline & \multicolumn{3}{|c|}{ Low $(\mathrm{N}=103)$} & \multicolumn{3}{|c|}{ Middle $(\mathrm{N}=150)$} & \multicolumn{3}{|c|}{ High $(\mathrm{N}=57)$} \\
\hline & $\begin{array}{l}10-14 \\
\text { years }\end{array}$ & $\begin{array}{l}14-16 \\
\text { years }\end{array}$ & $\begin{array}{ll}\mathrm{t} \\
\text { value }\end{array}$ & $\begin{array}{l}10-14 \\
\text { years }\end{array}$ & $\begin{array}{l}14-16 \\
\text { years }\end{array}$ & $\begin{array}{l}\mathrm{t} \\
\text { value }\end{array}$ & $\begin{array}{l}10-14 \\
\text { years }\end{array}$ & $\begin{array}{l}14-16 \\
\text { years }\end{array}$ & $\begin{array}{ll}\mathrm{t} \\
\text { value }\end{array}$ \\
\hline $\begin{array}{l}\text { Physical } \\
\text { (P) }\end{array}$ & $\begin{array}{l}101.50 \\
(17.78)\end{array}$ & $\begin{array}{l}100.39 \\
(15.23)\end{array}$ & 0.33 & $\begin{array}{l}89.86 \\
(13.66)\end{array}$ & $\begin{array}{l}85.25 \\
(13.18)\end{array}$ & $2.03 *$ & $\begin{array}{l}92.35 \\
(14.86)\end{array}$ & $\begin{array}{l}83.75 \\
(6.00)\end{array}$ & $2.47 *$ \\
\hline $\begin{array}{l}\text { Emotional } \\
\text { (E) }\end{array}$ & $\begin{array}{l}47.35 \\
(8.56)\end{array}$ & $\begin{array}{l}49.39 \\
(7.06)\end{array}$ & 1.27 & $\begin{array}{l}45.15 \\
(6.23)\end{array}$ & $\begin{array}{l}48.89 \\
(8.06)\end{array}$ & $3.18 * *$ & $\begin{array}{l}45.41 \\
(7.62)\end{array}$ & $\begin{array}{l}44.40 \\
(5.05)\end{array}$ & 0.53 \\
\hline $\begin{array}{l}\text { Cumulative } \\
(\mathrm{P}+\mathrm{E})\end{array}$ & $\begin{array}{l}148.85 \\
(22.08)\end{array}$ & $\begin{array}{l}149.78 \\
(19.71)\end{array}$ & 0.22 & $\begin{array}{l}135.01 \\
(15.75)\end{array}$ & $\begin{array}{l}134.14 \\
(16.77)\end{array}$ & 0.32 & $\begin{array}{l}137.76 \\
(16.70)\end{array}$ & $\begin{array}{l}128.15 \\
(6.47)\end{array}$ & $2.47 *$ \\
\hline
\end{tabular}

$* \mathrm{p}<.05, * * \mathrm{p}<.01$

In the overall context, there are no significant differences in the scores received by the younger and older adolescents from the low and middle class families; significant differences are, however, recorded in the adolescents from high status families; the younger adolescents experience more abuse than the older ones (t-value $=2.47 ; \mathrm{p}<.05)$. 


\section{DISCUSSION AND CONCLUSION}

It is apparent that abuse is prevalent in all the social classes but the adolescents from the low socio-economic status families experience the maximum abuse as compared to those from the middle and high socio-economic status families. These inferences are supported by the results of various earlier studies conducted in India and abroad where such conclusions were drawn (Garbarino, 1976; Gelles, 1973; Grewal, 1982; Khanna, 1987; Mahajan \& Madhurima, 1995; Nain, 1985; Prasad, 2001; Reid \& taplin, 1976; Suneet, 1983; United States Department of Health and Human Services, 1981). Kewalramani (1996) also points out that a large number of physically abused children (about $60 \%$ ) belong to poor families and only a small proportion (about $2 \%$ ) belong to well to do families. Chawla (2011) also reported that parents from low socio-economic status families are more punitive and exhibit severely harsh attitude towards their adolescent children compared to parents from middle and high socio-economic status families. Research has consistently shown that parents with low incomes and less access to resources have poorer socialization practices and less authoritative parenting styles, compared to more financially well-off parents (Magnuson \& Duncan 2002).

There are also considerable number of reports contradicting the negative relationship between the abuse and the socio-economic status. Nath and Kohli (1988), Steele and Pollock (1974) and Suneet (1983) opine that since abuse occurs at all levels of socio-economic system hence it is difficult to consider a social class as a cause of child abuse. Moreover, Berger (1980) reports that socio-economic class of the abusing families is a factor which differs across the studies. However, the pressures associated with undesirable economic change like low or unpredictable income, material deprivation and lack of social status due to job loss, may increase the likelihood of family tension, produce feeling of frustration and anger which may be displaced onto the child (Steinberg, Catalano \& Dooley, 1981). The observation that the children from poor families suffer more from abuse may also be due to the fact that the parents in the middle and upper classes are more capable of concealing the abuse because of availability of resources. Also the fact that some researchers have taken into consideration only the physical abuse with respect to socio-economic status rather than the total (physical and emotional) abuse, which may also be responsible to show more abuse in poor families.

Female adolescents score high on emotional abuse. This may be attributed to the fact that adolescence is a very sensitive phase of human life and it is a transitional stage between childhood and preparation for adulthood roles. Apart from physical development, adolescent

years are characterized by significant psycho-social development which has long lasting effects on the attitude and behaviour of adolescents hence they are perturbed easily and frequently. Literature also reveals that in the area of emotional abuse, the incidence rates increase gradually with increasing age for both the sexes (Smith, 1995). Whereas Prasad (2001) opined that younger children are at the greatest risk for physical abuse though the peak ages for such abuse vary from country to country (Krug et al., 2002). An overwhelming majority of respondents have been reported to be resorting to physical violence while dealing with younger generation (Mahajan 
and Madhurima, 1995). However, Kewalramani (1996) revealed that older children are more abused physically than younger children. In a study conducted in Yemen by Alyahri and Goodman (2008), more than half of the rural caregivers and about a quarter of the urban caregivers reported using harsh corporal punishment (hitting children with implements, tying them up, pinching or kicking them) with their children. Harsh corporal punishment was significantly associated with poor school performance with both behavioral and emotional difficulties. More boys compared to girls experienced harsh corporal punishment due to their annoying behavior. In a multi-level stratified random school-based survey conducted in China, results revealed that 22.30 per cent boys experienced more severe forms of physical punishment whereas girls experienced mild form of aggressive behavior such as yelling, scolding and slapping by their parents (Wang et al 2009).

Findings of the present study suggest that though abuse is ubiquitous in all the socio-economic classes (low, middle and high) but its prevalence is more in the adolescents belonging to poor families (low socio-economic status families). Though gender and age of the adolescents do not matter in the overall context of the abuse but significant differences do occur when the two components of abuse, that is physical and emotional, are considered separately. Girls are more prone to the emotional abuse irrespective of the social class and the older adolescents are more abused emotionally as compared to their younger counterparts. Considering the physical abuse, the younger adolescents are more abused than the older ones.

Hence, there is a dire need to educate the parents regarding appropriate child care and rearing skills by organizing trainings, seminars and through media so that our young generation does not become the target of parental stress and is not deprived of their rights and privileges.

\section{REFERENCES}

1. Alyahri, A. \& Goodman, R. (2008). Harsh corporal punishment of Yemen children: Occurrence, type and associations. Child Abuse and Neglect; 32:766-773.

2. Berger, A. M. (1980). The Child abusing family: Child and child rearing variables, environmental factors and typologies of abusing families. In D. H. Olson and B. C. Miller (Eds.). Family studies and review yearbook (pp. 265-281). New Delhi: Sage Publications.

3. Census of India (2011). Rural urban distribution of population. Registrar General and Census Commissioner, India.

4. Chawla, M. (2011). Harsh parenting: A determinant of aggression among adolescents in rural Families. Masters Thesis, Punjab Agricultural University, Ludhiana, Punjab.

5. Deb, S. (2006). Children in agony-A source book. New Delhi: Concept Publishing Company.

6. Deb, S. \& Senapati, S. ( 1993). Safety needs of abused Proletarian Bengalee children (Major modes of causal factors). Indian Journal of Psychological Issues; 1 (1): 1-9. 
7. Garbarino, J. (1976). A preliminary study of some ecological correlates of child abuse: The impact of socio-economic stress on mothers. Child Development; 47 (1-2): 178185.

8. Gelles, R. J. (1973). Child abuse as psychopathology: A sociological critique and reformulation. American Journal of Orthopsychiatry; 43, 611-621.

9. Grewal, B. (1982). Family violence: a case study of slum dwellers of Chandigarh. Maser of Philosophy Thesis. Panjab University, Chandigarh.

10. Horwood, L. J., Ferguson, D. M., Chesney, A. \& Woodward, L. J. (2007). Punitive practices of contemporary young parents. New Zealand Medicine Journal; 120:12671278.

11. Kewalramani, G. S. (1992). Child abuse: A sociological study of working and nonworking children. Jaipur, India: Rawat Publications.

12. Kewalramani, G. S. (1996). Child Abuse: A system analysis. Indian Journal of Social Work; 57 (1-4): 396-413.

13. Khanna, S. (1987). Social correlates of child battering. Master of Philosophy Thesis. Panjab University, Chandigarh.

14. Krug, E. G., Dalberg, L. L., Mercy, J. A., Zwi, A. B. \& Lozano, R. (2002). Child abuse and neglect by parents and other caregivers. In World report on violence and health (pp. 57-81). Geneva: World Health Organization.

15. Kulshrestha, S. P. (1988). Manual for socio-economic status scale (SESS FORM B: Rural). Agra, India: National Psychological Corporation.

16. Magnuson, K. \& Duncan, G. (2002) Parents in poverty. In: Bornstein M H (ed) Handbook of parenting. Vol 5, Pp 95-122. Lawrence Erlbaum Associates Publishers, Mahwah, New Jersey.

17. Mahajan, A. \& Madhurima (1995) Family violence and abuse in India. New Delhi: Deep and Deep Publications.

18. Nain, K. (1985). Child abuse: A case study of Hassangarh village in Haryana. Master of Philosophy Thesis. Panjab University, Chandigarh.

19. Nath, N. \& Kohli, M. (1988). Child abuse in India: Some issues-A background paper. Paper presented at the National Seminar on Child Abuse in India. Symposium conducted at the National Institute of Public Cooperation and child Development, New Delhi, June 22-24.

20. National Research Council (1993). Understanding child abuse and neglect. Washington, DC: National Academy Press.

21. NIPCCD (1988). Child abuse in India: Report of a national seminar. New Delhi: National Institute of Public Cooperation and Child Development.

22. Parke, R. D. \& Collmer, C. W. (1975). Child abuse: An interdisciplinary analysis. In Hetherington (Ed.). Review of child development research (Vol. 5) (pp. 509-589). Chicago: University of Chicago Press. 
23. Prasad, B. D. (2001). Maternal employment and child abuse. The Indian Journal of Social Work; 62 (3): 328-346.

24. Reid, J. B. \& Taplin, P. S. (1976). A social interactional approach to the treatment of abusive families. Paper presented to the American Psychological Association, Washington, DC.

25. Sharan, M. B. (1995). Child abuse and neglect in Indian families. Kharagpur, India: Department of Humanities and Social Sciences, Indian Institute of Technology.

26. Singh, A. \& Khokhar, C. P. (2005). Perception of parental acceptance and protection in children of single parents. Indian Psychological Review; 64 (3):143-152.

27. Smith M. A. (1995). A community study of physical violence to children in the home and associated variables. Poster presented at International Society for the Prevention of Abuse and Neglect: V European Conference, Oslo, Norway.

28. Steele, B. F. \& Pollock, C. B. (1974). A psychiatric study of parents who abuse infants and small children. In R. F. Hilter and C. H. Kempe (Eds.). The battered child (pp. 103-147). Chicago: University of Chicago Press.

29. Steinberg, L. D., Catalano, R. \& Dooley, D. (1981). Economic antecedents of child abuse and neglect. Child Development; 52 (3-4): 975-985.

30. Steinmetz, S. K. (1978). Violence between family members. Marriage and Family Review; 1 (3): 1-16.

31. Suneet (1983). A battered child syndrome: A study in family violence. Master of Philosophy Thesis. Panjab University, Chandigarh.

32. United States Department of Health and Human Services (1981). Study findings: National study of the incidence and severity of child abuse and neglect. DHHS, Publication No. (OHDS) 8130325, 22-56.

33. Walker, C. E., Bonner, B. L. \& Kaufman, K. (1988). The physically and sexually abused child. New York: Pergamon Press.

34. Wang, L., Liu, M., Chen, X., Zheng, S. \& Chen, H. (2009). Maternal autonomy- and connectedness- oriented parenting behaviors as predictors of children's social behaviors in China. Social Development; 18: 671-689. 